University of Nebraska - Lincoln

DigitalCommons@University of Nebraska - Lincoln

Faculty Publications from the Harold W. Manter Laboratory of Parasitology

Parasitology, Harold W. Manter Laboratory of

1994

New Records of Bolivian Mammals

Jorge A. Salazar-Bravo

Texas Tech University, j.salazar-bravo@ttu.edu

Mariel Campbell

University of New Mexico, campbell@carachupa.org

Sydney Anderson

American Museum of Natural History

Scott Lyell Gardner

University of Nebraska - Lincoln, slg@unl.edu

John L. Dunnum

University of New Mexico, jldunnum@unm.edu

Follow this and additional works at: https://digitalcommons.unl.edu/parasitologyfacpubs

Part of the Biodiversity Commons, Parasitology Commons, and the Zoology Commons

Salazar-Bravo, Jorge A.; Campbell, Mariel; Anderson, Sydney; Gardner, Scott Lyell; and Dunnum, John L., "New Records of Bolivian Mammals" (1994). Faculty Publications from the Harold W. Manter Laboratory of Parasitology. 80.

https://digitalcommons.unl.edu/parasitologyfacpubs/80

This Article is brought to you for free and open access by the Parasitology, Harold W. Manter Laboratory of at DigitalCommons@University of Nebraska - Lincoln. It has been accepted for inclusion in Faculty Publications from the Harold W. Manter Laboratory of Parasitology by an authorized administrator of DigitalCommons@University of Nebraska - Lincoln. 


\section{New Records of Bolivian Mammals}

\section{by J. A. Salazar ${ }^{1}$, M. L. Campbell ${ }^{2}$, S. Anderson ${ }^{3}$, S. L. Gardner ${ }^{2}$ and J. L. Dunnum ${ }^{1}$}

${ }^{1}$ Museum of Southwestern Biology, University of New Mexico, Albuquerque, NM, USA

${ }^{2}$ Department of Nematology, University of California, Davis, CA, USA

${ }^{3}$ American Museum of Natural History, New York, NY, USA Contact E-mails: Salazar: j.salazar-bravo@ttu.edu, Gardner: slg@unl.edu, Dunnum: jldunnum@unm.edu

Summary. We present new records for Bolivian mammals that have been gathered in 1991 and 1992. The first specimen of Chironectes minimus from Bolivia and new localities of distribution for Monodelphis kunsi and Dactylomys boliviensis are reported.

Résumé. Nous présentons de nouvelles données sur des mammifères boliviens qui ont été collectés en 1991 et 1992. Nous rapportons la découverte des premiers spécimens de Chironectes minimus de Bolivie ainsi que des nouvelles localités de capture de Monodelphis kunsi et Dactylomys boliviensis.

\section{INTRODUCTION}

We present new records of occurrence and distribution for two species of didelphid marsupials and one species of echimyid rodent. Specimens were obtained from May through August 1991 and June through August 1992 in a study of mammalian diversity of Bolivia, a joint project between the Colección Boliviana de Fauna in La Paz, the Museum of Southwestern Biology (University of New Mexico), the American Museum of Natural History (New York), the Museo "Noel Kempff Mercado" de Historia Natural in Santa Cruz de la Sierra, and the University of California at Davis. This project is an attempt to strength Bolivian collections of natural history as well as to increase the knowledge of the mammals of one of the richest yet still poorly known areas of South America.

Specimens were prepared following museum standards and are on deposit in one of these collections. We also obtained tissues (heart, liver and kidney) and parasites for future studies. Most of the individuals were karyotyped and cell suspensions frozen in liquid nitrogen. All tissues, karyotypes and cell suspensions were deposited in the Division of Biological Materials, Museum of Southwestern Biology, University of New Mexico. 


\section{LOCALITIES}

La Reserva: Departamento La Paz, La Reserva, elevation $840 \mathrm{~m}, 15^{\circ} 44^{\prime} \mathrm{S}$ and $67^{\circ} 31^{\prime} \mathrm{W}$, in the province of Nor Yungas.

The village of La Reserva is close to rio La Reserva, a small tributary of the Caranavi River. The village is in the bottom of a valley in the subtropical montane forest that covers most of the eastern Andean slopes between $15^{\circ}$ and $17^{\circ} \mathrm{S}$ latitude in the Cordillera Oriental of Bolivia. The foothills at this elevation are covered with semideciduous vegetation intermingled with columnar cacti and bromeliads, especially along roads and eroded surfaces. The forest is drier and more sparse than at higher elevations. The trees are smaller, more highly branched, and most grow in open sun versus the deep shade of the dense canopy typical of higher elevations. The east-facing slope above the river is steep, with much vegetation, some secondary growth and banana and tangerine cultivation. Palms and tree ferns are absent.

The river La Reserva is a small fast-flowing second order stream running south. The streambed is $20 \mathrm{~m}$ wide, stream width is between 8 and $12 \mathrm{~m}$ and the depth ranges from $10 \mathrm{~cm}$ to $1 \mathrm{~m}$. The stream is interrupted by boulders of about $1.5 \mathrm{~m}^{3}$, sedimentary in origin and different from the metamorphic rocks that give support to the walls of the valley and parts of the riverbed. The east bank is an alluvial terrace where the original vegetation has been partially replaced by the cultivation of bananas, oranges, tangerines and vegetables. Secondary vegetation is also present as evidenced by the presence of Cecropia spp. and a mixture of bamboo and caña brava (cf. Gynerium spp.).

Tapecua: Tapecua lies at the crest of a divide in a small mountain ridge that is the eastern-most of the Cordillera Oriental, on the border of the Bolivian Chaco. The forest is composed of broad-leaved and leguminous trees at an elevation of 1,500 $\mathrm{m}$, with a few columnar cacti, steep forested slopes, dense canopy between 7 and $10 \mathrm{~m}$ (up to 60 or $80 \%$ of cover), with little ground cover except dead leaves, fallen logs, rocks and some forbs. The valley on the eastern flank of this mountain system, runs from east to west and has forested slopes both on the north and south.

\section{ACCOUNTS OF SPECIES}

\section{Chironectes minimus (Zimmermann, 1780)}

The water opossum or yapok (Chironectes minimus) is a unique South American marsupial, distinguished by its aquatic habits, morphological characters and color of pelage (Marshall 1978).

The known geographic range of $C$. minimus extends from southern Mexico and Belize south to Paraguay and northern Argentina and from western Brazil to Ecuador, including Colombia, the Guianas and Peru (Emmons and Feer 1990).

There are two published sight records of this species from Bolivia, but the specimens reported here are the first collected in that country. Dunstone (1987) observed one individual in Amboro National Park. Cabot (1989) reported seeing an individual in "... a backwater stream in the vicinity of Campamento 6 de Agosto $\left(15^{\circ} 30^{\prime} \mathrm{S}\right.$ and $\left.71^{\circ} 10^{\prime} \mathrm{W}\right)$ [sic]..." in the Department of Beni. These coordinates, however, correspond to a Peruvian locality. The approximate coordinates of Campamento 6 de Agosto are $15^{\circ} 17^{\prime} \mathrm{S}$ and $67^{\circ} 05^{\prime} \mathrm{W}$. 
Between July 22 and 29, 1992, we collected seven specimens of C. minimus: five adult males, one young male and one adult female at La Reserva.

We observed water opossums along about $250 \mathrm{~m}$ of the Rio La Reserva. Their behavior was similar at all observation points, with the animals moving through shallow water (different animals every 5 to 20 minutes) floating downstream or actively swimming upstream. We made observations of the animals between 2000 (hour when the first animals usually appeared) to well after midnight. The animals were solitary except in cases of youngsters swimming with adult females.

The female, that was collected had five well-developed (> $7 \mathrm{~mm}$ ) nipples, suggesting nursing offspring.

\section{Monodelphis kunsi Pine, 1975}

Anderson (1982) reported the second specimen of this very poorly known species, and noted that Monodelphis kunsi was probably one of the smallest species in the genus. He also reported that "... nothing is known of the [ecology], behavior and genetics of this species...." We report here three additional specimens collected from two different localities in Bolivia.

This species is known only from Bolivia, but probably occurs in both Brazil and Argentina due to the proximity of these countries to the Bolivian localities.

The type locality and northeasternmost record is Departmento Beni, Provincia Itenez, La Granja, W bank of Rio Itonamas, $4 \mathrm{~km} \mathrm{~N}$ Magdalena. 13² $18^{\prime} \mathrm{S}, 64^{\circ} 09^{\prime}$ W (below $200 \mathrm{~m}$ ). The second location is Departamento Tarija, Rio Lipeo, $640 \mathrm{~m}$, $22^{\circ} 41^{\prime} \mathrm{S}$ and $64^{\circ} 26^{\prime} \mathrm{W}$. We collected (July 10, 1991) one individual at Departamento Tarija; Tapecua, 1,500 m, 21 $26^{\prime} \mathrm{S}$ and $63^{\circ} 55^{\prime} \mathrm{W}$ and two additional individuals (July 24/26, 1992) from Departamento La Paz, La Reserva, 840 m, 15²4' $\mathrm{S}$ and $67^{\circ} 31^{\prime} \mathrm{W}$.

The trapline where M. kunsi was collected at Tapecua was along a ravine on a southwest-facing slope with dense shrubs. The trapsite had many rocks and much fallen wood, and the ground had 10 or $12 \mathrm{~cm}$ of leaf mulch and litter on the surface. The slope at this specific point was about 300 and less than $5 \%$ of the ground cover was composed of small forbs and ferns.

The specimens collected at La Reserva were taken in a banana field some $30 \mathrm{~m}$ from the river on the moderately disturbed terrace. The canopy began at 7 or $8 \mathrm{~m}$ and provided 20 to $50 \%$ cover. Shrubs formed about $10 \%$ of the cover and the area was almost flat. The soil was very moist, with high organic content and at least 2 $\mathrm{cm}$ of leaf litter.

Both areas seem to be representatives of a moderately disturbed ecosystem, such as that described by Anderson (1982).

We collected the specimen at Tapecua during the day, between 0830 and 1630 . The specimens from La Reserva were collected on the same trapline two days apart.

The three specimens are females but none was pregnant or lactating.

\section{Dactylomys boliviensis Anthony, 1920}

The bamboo rats (Dactylomys) are echimyid rodents that are characterized by their strong smell produced by a odoriferous gland over the sternum, their primate-like grasping feet and a peculiar vocalization that resembles that of a toad.

Nowak (1991) and Cabrera (1961) recognized three species, D. dactylinus, D. pe- 
ruanus, and D. boliviensis, but some other authors seem to imply the existence of only two species, D. dactylinus and D. peruanus (Emmons and Feer 1990).

Although both Cabrera (1961) and Honacki et al. (1982) mentioned D. boliviensis as occurring in central Bolivia and Southeastern Peru, to our knowledge no other records exist except four localities mentioned by Anderson (in preparation) and one locality mentioned in a report by Parker and Bailey (1991), all in Bolivia: Departamento Beni : $4 \mathrm{~km} \mathrm{~S}$ of Guayaramerin (10 $\left.51^{\prime} \mathrm{S} / 65^{\circ} 25^{\prime} \mathrm{W}\right)$; Departamento Cochabamba; San Antonio (16 $57^{\prime} \mathrm{S} / 65^{\circ} 24^{\prime} \mathrm{W}$ and type locality for the species); De-

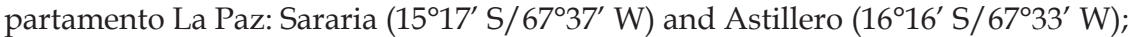
and Alto Madidi (no specific locality given).

Between July 22 and 29, 1992, we collected four specimens: two females, one male and one young of unknown sex at Departamento La Paz, La Reserva, 840 m, $15^{\circ} 44^{\prime} \mathrm{S}$ and $67^{\circ} 31^{\prime} \mathrm{W}$.

Dense stands of bamboo (cf. Bambusa, forming patches of up to $1 \mathrm{~km}^{2}$ ) and small trees form a thick canopy at approximately 5 to $8 \mathrm{~m}$, with an understory of intertwining branches, vines and dead leaves. In the clearings, every tree is covered with a broadleafed vine which forms a mat 3 to $5 \mathrm{~m}$ above the ground.

We first detected this species in the area by their characteristic calls. All of the specimens we obtained were within a radius of $5 \mathrm{~m}$, although on three different nights. The first individual was a calling male. Two nights and $3 \mathrm{~m}$ away from where the first animal was taken, an adult female and a young individual of unknown sex were perched $2.5 \mathrm{~m}$ above the ground. The adult female was vocalizing. One night later, we collected another female that was perching alone, $2 \mathrm{~m}$ from the place of first collection. This female was also calling. A specimen of Oecomys was seen in this patch of bamboo.

Vocalizing of Dactylomys was heard between 1900 and 0400 hours, and were more frequent between 2200 and 0245 hours.

Stomach contents included bamboo sprouts and bamboo epidermis. This coincides with gnawing/tooth marks on the bamboo trunks near where animals were collected.

One of the females was pregnant with two well-developed embryos of 74 and $82 \mathrm{~g}$.

\section{DISCUSSION}

Chironectes minimus is a very widely distributed, easily identifiable but uncommon species, living near running clear water. The nearest specimen record to Bolivia was some 500 Ian to the northwest (Marcapata y Moyobamba in Peru, Marshall 1978). This Bolivian record is probably near its southernmost limit of distribution on the west margin of the Amazon basin, because farther south the habitats become dryer as we approach the Chaco.

Whether Dactylomys boliviensis is a valid species or simply a synonym of $D$. dactylinus is something that needs to be determined. The information gathered in the field, suggests that both have similar behavior. If Dactylomys boliviensis is as ecologically restricted as D. dactylinus (Emmons 1981), we may assume that the former could also be used as an index of habitat quality. The only noteworthy difference from information reported by Emmons (1981) is that adult females call while perching. 
The Bolivian bamboo rat (Dactylomys boliviensis) was described by Anthony (1920) based on one specimen collected by Leo E. Miller and H. S. Boyle on August 18, 1915. Anthony (1920), differentiated D. boliviensis and D. dactylinus, because of small differences in coloration and skull characters.

Monodelphis kunsi seems to prefer moderately disturbed habitats as reported by Anderson (1982). The species is not common, but seems to have a wide distribution in the eastern lowlands of Bolivia and some of the eastern flanks of the Andean Cordillera. The record from Tapecua expands the known elevational range about $800 \mathrm{~m}$ (from about 640 to 1,500 m), for a total elevational distribution that ranges from below $200 \mathrm{~m}$ to at least $1,500 \mathrm{~m}$.

Anderson (1982) mentioned the presence of white markings on the venter in this species and Emmons and Feer (1990) mentioned $71 \mathrm{~mm}$ as the head and body length (HB) for this species. Two of our specimens (the one from Tapecua and the adult female from La Reserva) showed the white marking, while the young individual from La Reserva did not. Nevertheless, all three of our specimens had HB lengths longer than $71 \mathrm{~mm}$ (range 74-94 $\mathrm{mm}$ ), possibly because the measurements of Emmons and Feer (1990) are based on only one specimen. The actual range for HB should be 71-94 mm. Other external measurements were close to those reported by Anderson (1982).

We think that until a major effort is made to document and publish distribution data, both scientists and policemakers will have no access to basic information that will help them develop evolutionary hypotheses as well as environmental policies for the conservation of mammalian fauna.

\section{ACKNOWLEDGEMENTS}

This study had fmancial support of National Science Foundation grants numbers BSR 8920617, BSR 90-15454 and BSR 90-24816, additional funds were provided by the Latin American Institute and the Graduate Research Allocation Committee of the University of New Mexico (to JSB). Thanks to Richard Forbes, Eduardo Palma, Terry Yates, Norman Scott, Ryan Robino and two anonymous reviewers for reading and commenting on earlier versions of this manuscript.

Permission to collect in Bolivia was granted by the covenants with Coleccion Boliviana de Fauna in La Paz, Bolivia.

\section{BIBLIOGRAPHY}

Anderson, S., 1982. Monodelphis kunsi. Mammalian Species, no. 190: 1-3. American Society of Mammalogists.

Anthony, H. E., 1920. New rodents and new bats from neotropical regions. J. Mamm., 1 : 81-86.

Cabot, J., 1989. Second record of Chironectes minimus (Marsupialia) in Bolivia. Mammalia, 53: 135-136.

Cabrera, A., 1957-1961. Catalogo de los mamiferos de America del Sur. Revista del Museo Argentino de Ciencias Naturales «Bemandino Rivadavia» e Instituto Nacional de Investigacion de las Ciencias Naturales, Ciencias Zoologicas, 4: 1-307.

Dunstone, N., 1987. The quest for the river wolf. Final report, University of Durham expedition to Bolivia. Privately published.

Emmons, L. H., 1981. Morphological, ecological, and behavioral adaptations for arboreal brossing in Dactylomys dactylinus (Rodentia, Echimyidae). J. Mamm., 62 : 183-189. 
130 Salazar, Campbell, Anderson, Gardner \& Dunnum in Mammalia (1994) 58

Emmons, L. H., and F. Feer, 1990. Neotropical rainforest mammals. A field guide. The University of Chicago Press, Chicago.

Honacki, J. H., K. Kinmann et J. Koeppl, 1982. Mammal Species of the World: A Taxonomic and Geographic Reference. Allen Press, Lawrence, Kansas, 694 p.

Marshall, L. G., 1978. Chironectes minimus. Mamm. Species, 109: 1-6. American Society of Mammalogists.

Nowak, R. M., 1991. Walker's Mammals of the World. Fifth ed. Vol. I and II. The Johns Hopkins University Press. Baltimore, Maryland.

Parker, T. and B. Bailey, 1991. A Biological Assessment of the Alto Madidi Region. Conservation International, Washington. 